\title{
The Effect of Personality Traits on User Continuance Usage Intention of e-Filing System
}

\author{
T. Santhanamery and T. Ramayah
}

\begin{abstract}
Personality has been found to be related to broad spectrum of human activities and behavior. However, the effect of personality traits on technology adoption has not been widely researched. Eventually, as the usage of internet has shown a tremendous increase world-wide, it is reasonable to investigate its usage in terms of personality perspectives. Since the level of internet usage is voluntary rather than mandated, so it is more likely to reflect personal motives, needs, values, preferences and other personality attributes. Moreover, previous researcher had predicted that there is a possibility that future technology adoption decision will be more concern on human nature compared to usefulness factors. As such this paper proposed to investigate the effect of personality traits in encouraging the continued use of the e-filing system in Malaysia.
\end{abstract}

Index Terms-Personality, technology adoption, continuance usage intention, e-filing system.

\section{INTRODUCTION}

The term e-government or electronic government refers to the use of information technology by government agencies, such as web-based Networks, the Internet, and mobile computing, that have the ability to transform relations with citizens, businesses, and other arms of government [1]. A useful indicator to determine the status of e-government in developing countries is by comparing its e-government readiness index with the other countries [2]. Malaysia's ranking for e-government development index has improved from the ranking of 43 (2005) to 34 (2008) to 32 (2010) [3]. In South East Asia Category, Malaysia's ranking has also improved from $3^{\text {rd }}$ ranking (2005) to $2^{\text {nd }}$ raking in 2008 and 2010 but with an improved index [3]. In terms of e-Participation Index, there has been a tremendous improvement for Malaysia where its ranking improved from the placing of 41 (2008) to 12 (2010) [3]. In reality, all these rankings actually show the initiatives and technology developments made by Malaysian Government in making sure that the e-government services reach the citizens. These initiatives truly resemble the "supply side" of the e-government development delivery [4]. What about the "demand side"? To what extend the citizens are going to use or continually use these particular services? remains as an important question to be answered because countries can be high in e-government rankings which focus more on technology developments but a system is still considered a

Manuscript received November 10, 2012; revised January 29, 2013.

T. Santhanamery is with the Universiti Teknologi MARA Malaysia, 13500 Permatang Pauh Penang, Malaysia (e-mail: santhana_1@yahoo.com).

T. Ramayah is with the Universiti Sains Malaysia, 11800 Minden, Penang, Malaysia (e-mail:ramayah@gmail.com). failed system if the intended recipients do not use or continually use them [4]. Thus the underlying problem now is not the problem of design but utilization. The key to successful e-government depends very much on the utilization of the implemented systems [5].

Recent studies have found linkages between technology adoption and personal characteristics [6]-[9] indicating that personal characteristics do have an effect on technology adoption. Differences investigated in these studies were based on personal innovativeness, absorptive capacity, culture, personal awareness, and personal internet experience. Nevertheless, one factor that has not been widely investigated in technology adoption particularly in e-government context is personality of the users.

Personality has been found to be related to broad spectrum of human activities and behavior including romantic relationship [10], psychopathic [11], job performance [12], career success [13], job satisfaction [14], sex differences [15]. Furthermore, a number of recent studies also had suggested that personality is an important behavior in online environment [16] and [17]. Thus, it is necessary and timely to investigate the effect of personality on continuance usage intention in the context of e-government services.

One of the puzzling phenomena with regard to internet usage is the difference between internet users and e-services users. According to [18], there has been tremendous growth of internet users worldwide. In the context of Malaysia, internet users increase to $64.6 \%$ of the total population of 26.1 million. Indeed, Malaysia is ranked as one of the top ten countries in Asian region with the highest number of internet users. According to survey done by [19] in 2009 reveals that the main purpose of internet usage in Malaysia is for getting information $(76.9 \%)$ followed by communication by text $(74.8 \%)$, leisure $(50.1 \%)$, social networking (46.8\%), educational activities (46\%), financial activities (27.2\%), government services (19.6\%), maintain homepage (7\%) and others $(7.6 \%)$. This shows that users have actually become more like consumers in making decisions on their preferences to use, not to use or continually use a particular system [16]. While the difference has been empirically observed but it is still unclear the factor that contribute to this difference. Thus, this paper will explore the effect of personality traits on the continuance usage intention. The proposed research model will be tested on the tax payers and their continuance usage intention of e-filing system to file their tax online in Malaysia.

\section{E-FILING IN MALAYSIA}

The submission via e-filing has shown a tremendous 
increase since its launching in 2006 particularly for individual taxpayers. The number of submission grew from 186,271 (2006) to 873,095 (2007) [20] to $1,171,105$ (2008) to $1,466,507$ (2009) [21]. This shows that $30 \%$ of the total registered individual taxpayers $(4,785,452)$ have filed their income taxes via e-filing in 2009 [21]. Eventually, with the increasing number of taxpayers adopting e-filing system, a substantial amount of cost savings have been achieved. Up to $31^{\text {st }}$ May 2009, a total cost of RM9, 162,845.64 have been saved. The number has gradually increased since its introduction in 2006 (RM1, 302,590.40), 2007 (RM4, 876,564.64) and 2008 (RM8, 187,144.96). Such trends underlines the importance, relevance and timeliness of studying IS continuance as a topic of government interest.

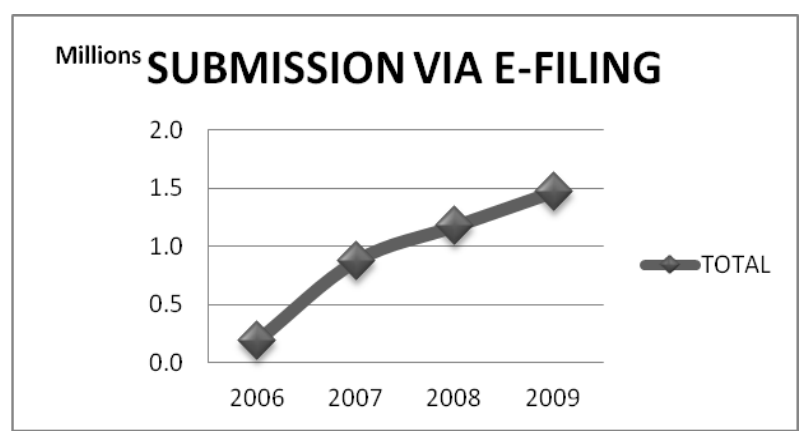

Fig. 1. Theoretical Background

Based on the evaluation of the theoretical finding from previous literatures concerning the personality variable and as well as the recommendation by previous researchers, the research model as illustrated in Fig. 2 were constructed to explore the relationships expected in this study. Basically, the theoretical framework proposed that personality will directly affects perceived usefulness towards e-filing continuance usage intention. Personality factor has been explored widely in different fields earlier; however it is getting its popularity among technology adoption researches recently. Researchers on personality traits [16], [17], [22] have reported that personality variable has a high impact on technology adoption. The major area of this study is the continuance usage intention, whereby customers' repurchasing or loyalty is critical to the success and profitability of online stores [23]. Significantly while there has been encouraging interest shown in determining continuance usage intention, however, very little effort is undertaken in determining the effect of personality on the continuance usage intentions particularly in e-government perspectives. Therefore, this study intends to fill the aforementioned gap.

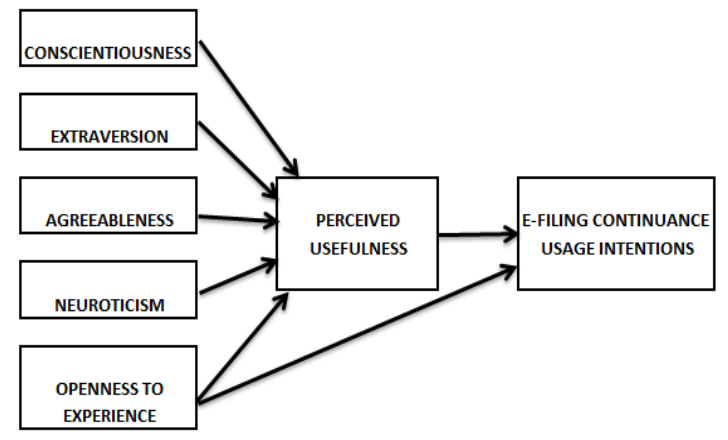

Fig. 2. The Proposed Research Model

\section{DESCRIPTION AND DEFINITION OF THE PROPOSED VARIABLES IN THE MODEL}

\section{A. Continuance Usage Intention}

Continuance usage intention is defined as ones intention to continue using or long term usage intention of a technology [24]. Research on IS continuance have been explored both at the organizational and individual level of analysis [25], for example [26] found that in order for an organizational innovation to be successful the organizational member must accept and utilize it. The individual level of analysis, which is also the focus of the present study, assumes that IS continuance behavior is the continued usage of IS by adopters, which is follows an initial acceptance decision [27]. In line with this, the research on e-government is taking a new phase with researches focusing more to evaluate the continued usage intention by the citizens rather than the initial intention. However, unlike initial acceptance decision, IS continuance depends on various factors that affect the individuals' decision to continually using a particular system [28]. Since the internet usage is voluntary, there is a strong possibility that the usage is reflected by the personality attributes [29].

\section{B. Perceived Usefulness}

Perceived usefulness was defined "as the prospective user's subjective probability that using a specific application system will increase his or her job performance within an organizational context [30]. Perceived usefulness has been subjected to widespread study by previous researchers (31, $32,33,34$, and 35]. It was found that perceived usefulness was correlated with all technology usage. Researches by [16, 36, 37, 38, and 39] establish that perceived usefulness has a significant positive influence on continuance usage intention of a technology. However, contradict to the other studies, [40] found no strong impact between perceived usefulness and continuance intention while [41] founds that there exist no relationship between perceived usefulness and continuance usage intention.

\section{Personality}

Research on personality has received great attention among scholars in different fields particularly of human activities and behavior. Personality is defined as an individual's disposition or tendencies that lead to certain attitudinal and behavioral patterns across situations [42]. Personality reflects the exceptional features of human being, the characteristics that defined the essence and it is reflected in all the thoughts and actions [17].

Several researches have begun the investigation on the affect of personality traits on technology adoption such as [17], [43]-[45]. However there is limited study on the effect of personality towards continuance usage intention. Therefore this study will attempt to identify the effect of personality traits (openness, conscientiousness, extraversion, neuroticism and agreeableness) on the perceived usefulness and confirmation towards the continuance usage intention of e-filing system.

Conscientiousness individuals are organized, reliable, hardworking, self-discipline, punctual, neat, ambitious and persevering type personality [46]. They are intrinsically 
motivated to achieve, perform at a higher level and take action to improve their job performance [17]. Thus, they will accept a particular technology only after a careful assessment of its opportunity for further achievement [17]. As such, they will be more readily perceived the e-filing system as useful.

Extraversion individuals are sociable, talkative, person-oriented, optimism, fun-loving and affectionate [46]. Rogers (1983) (cited in [17]) that gaining social status is the most motivation for individuals to accept and adopt an innovation. As such, they will have a more readily perceive the usefulness of the e-filing system.

Neuroticism individuals are worrying, nervous, emotional, insecure, inadequate and paranoid [46]. Ajzen and Fishbein's (1980) TRA identified neuroticism as one of the personality variables affecting beliefs about behavior (as cited in [17]). These individuals view technology advances as threatening and stressful and usually have negative thought about a technology [17] which could affect their thought about the perceived usefulness of a technology [16].

Agreeableness individuals are soft-hearted, good natured, trusting, helpful, forgiving and straight forward [46]. Agreeable personalities are more likely to accommodate and cooperative when considering a new technology and focus on the positive and cooperative dimensions of the technology [17]. Since e-filing system is a new technology used to file the tax online, thus it should be affected by this agreeable personality who may accept the system as useful.

Openness individuals are curious, broad interests, creative, original, imaginative and untraditional [46]. They are also defined as the individuals who like to explore unfamiliar or new things [46] and value changes [42]. Thus, it is possible that individuals who scores high on openness may be willing to learn new technologies and be less worried about the new technology [47] such as e-filing system. Due to their personality, they can easily perceive the system as useful and ever willing to continue using the new technology

Considering all these factors, we propose the following hypotheses:

1) Conscientiousness will be positively associated with the perceived usefulness of the e-filing system continuance usage intention

2) Extraversion will be positively associated with the perceived usefulness of the e-filing system continuance usage intention

3) Neuroticism will be negatively associated with the perceived usefulness of the e-filing system continuance usage intention

4) Agreeableness will be positively associated with the perceived usefulness of the e-filing system continuance usage intention

5) Openness to experience will be positively associated with the perceived usefulness of the e-filing system continuance usage intention

6) Openness to experience will have a direct impact towards the e-filing system continuance usage intention

\section{RESEARCH METHODOLOGY}

To test these proposals, a set of self-administered questionnaires survey will be used upon those taxpayers in the northern region of Malaysia consist of Penang, Kedah and Perak. The unit of analysis chosen for this study is the individual salaried taxpayers who have used the e-filing system to file their tax online at least once. The reason individual salaried taxpayers are chosen is due to the fact that they are the pioneering group who used the e-filing system and the largest group of taxpayers in Malaysia. Data will be analyzed using the Partial Least Squared Method (PLS).

\section{CONCLUSION}

Many of the existing studies on individual adoption of information technology (IT) have focused on investigating the intention to use or to adopt an IT, while less attention is paid to the post adoption environment where individuals decides whether to continue or discontinue using an IT [48]. It is observed that in most cases after "initial usage" of e-government services many users revert to traditional ways for acquiring information and services, therefore engaging and retaining citizens for "continued usage" are a challenge faced by most government agencies providing online public services [49].

Practically, this study will highlight the various personality traits and the influence of this personality on satisfaction and attitude. By understanding the personality perspectives of citizens it will assist government leaders in the implementation or designing any other e-government projects in future whereby personality traits should be carefully considered and explored in relation to belief, attitude and experience. Indeed, [50] had predicted that there is a possibility that future technology adoption decision will be more concern on human nature compared to usefulness factors.

\section{REFERENCES}

[1] Z. Fang, "e-Government in Digital Era: Concept, Practice and Development," International Journal of the Computer, the Internet and Management, vol. 10, no. 2, pp. 1-22, 2002.

[2] S. Bhatnagar, Unlocking E-Government Potential: Concepts, Cases and Practical Insights, $1^{\text {st }}$ ed, SAGE Publications India Pvt Ltd, 2009.

[3] United Nations E-Government Survey (UNPAN). (2010). Leveraging E-Government at a Time of Financial and Economic Crisis. [Online]. Available:

http://unpan1.un.org/intradoc/groups/public/documents/un/unpan0388 51.pdf.

[4] R. Gauld, S. Goldfinch, and S. Horsburgh, "Do they want it? Do they use it? The 'Demand-Side' of e-Government in Australia and New Zealand,' Government Information Quarterly, vol. 27, no. 2, pp. 177-186, 2010.

[5] Economist. (2008). The God, the Bad and the Inevitable: The pros and cons of e-government. [Online]. Available: http://www.economist.com/node/10638105?story_id=10638105.

[6] Y. K. Lee, J. H. Park, N. Chung, and A. Blakeney, "A Unified Perspective on the Factors Influencing Usage Intention Toward Mobile Financial Services," Journal of Business Research, 2011.

[7] N. Kassim and N. A. Abdullah, "The effect of perceived service quality dimensions on customer satisfaction, trust, and loyalty in e-commerce settings: A cross cultural analysis," Asia Pacific Journal of Marketing and Logistics, vol. 22, no. 3, pp. 351-371, 2010.

[8] P. Ying, C. Sirion, and C. Howard, "A Study of the Factors Influencing Online Purchase Intention of Consumers in China," American Society of Business and Behavioral Sciences e-Journal, vol. 6, no. 1, pp. 88-99, 2010.

[9] Y. K. Lee, J. H. Park and N. Chung, "An Exploratory Study on Factors Affecting Usage Intention toward Mobile Banking: A Unified 
Perspective Using Structural Equation Modelling," Society for Marketing Advances Proceedings, pp. 347-360, 2009.

[10] P. R. Shaver and K. A. Brennan, "Attachment Styles and the "Big Five" Personality Traits: Their Connections with Each Other and with Romantic Relationship Outcome," Personality and Social Psychology Bulletin, vol. 18, pp. 536-545, 1992.

[11] S. O. Lilienfeld and B. P. Andrews, "Development and Preliminary Validation of a Self-Report Measure of Psychopathic Personality Traits in Noncriminal Population," Journal of Personality Assessment, vol. 66, no. 3, pp. 488-524, 1996

[12] J. F. Salgado, "The Five Factor Model of Personality and Job Performance in the European Community," Journal of Applied Psychology, vol. 82, no. 1, pp. 30-43, 1997.

[13] S. E. Seibert, M. L. Kraimer, and J. M. Crant, "What Do Proactive People Do? A Longitudinal Model Linking Proactive Personality and Career Success," Personnel Psychology, vol. 54, pp. 845-874, 2001.

[14] T. A. Judge, D. Heller, and M. K. Mount, "Five-Factor Model of Personality and Job Satisfaction: A Meta-Analysis," Journal of Applied Psychology, vol. 87, no. 3, pp. 530-541, 2002.

[15] D. P. Schmitt, A. Realo, M. Voracek, and J. Allik, "Why Can't a Man Be More Like a Woman? Sex Differences in Big Five Personality Traits Across 55 Cultures," Journal of Personality and Social Psychology, vol. 94, no. 1, pp. 168-182, 2008.

[16] M. Y. C. Lin and C. S. Ong, "Understanding Information System Continuance Intention: A Five Factor Model of Personality Perspectives," in Proc. the Pacific Asia Conference on Information System (PACIS), paper 52, pp. 366-376, 2010.

[17] S. Devaraj, R. F. Easley, and J. M. Crant, "How Does Personality Matter? Relating the Five Factor Model to Technology Acceptance and Use," Information System Research, vol. 19, no. 1, pp. 93-105, 2008.

[18] Internet World Stats. (2010). Internet Usage in Asia. [Online]. Available: http://www.internetworldstats.com/stats3.htm.

[19] Malaysian Communication and Multimedia Commission. (2009) Household Use of the Internet Survey. [Online]. Available: http://www.skmm.gov.my/link_file/facts_figures/stats/pdf/inlayHUIS 2009.pdf.

[20] Annual Report Inland Revenue Board of Malaysia. (2007). [Online]. Available: http://www.hasil.gov.my/pdf/pdfam/AR2007_2. pdf.

[21] Annual Report Inland Revenue Board of Malaysia. (2009). [Online]. Available: http://www.hasil.gov.my/pdf/pdfam/AR2009_2.pdf.

[22] N. Mohamed, R. Hussein, and N. H. A.Zamzuri, "Modeling Online Repurchase Intention in A Developing Country: The Case Of Malaysia," Journal of e-Business, vol. 10, no. 1, pp. 33-37, 2010.

[23] C. M. Chiu, C. C. Chang, H. L. Cheng, and Y. H. Fang, "Determinants of Customer Repurchase Intention in Online Shopping," Online Information Review, vol. 33, no. 4, pp. 761-784, 2009.

[24] A. Bhattacherjee, "A. Understanding Information Systems Continuance: An Expectation-Confirmation Model," MIS Quarterly, vol. 25 , no. 3, pp 351-370, 2001.

[25] M. Limayem, S. G. Hirt, and C. M. K. Cheung, "How Habit Limits the Predictive Power of Intention: The Case of Information System Continuance," MIS Quarterly, vol. 31, no. 4, pp. 705-737, 2007.

[26] R. W. Zmud, "Diffusion of Modern Software Practices: Influence of Centralization and Formalization," Management Science, vol. 28, no. 12, pp. 1421-1431, 1982.

[27] H. W. Kim, H. C. Chan, and Y. P. Chan, "A Balanced Thinking-Feelings Model of Information Systems Continuance," International Journal of Human Computer Studies, vol. 65, no. 6, pp. $511-525,2007$.

[28] M. Limayem, S. G. Hirt, and W. W. Chin, "Intention Does Not Always Matter: The Contingent Role of Habit on IT Usage Behavior," The $9^{t h}$ European Conference on Information Systems, pp. 274-286, 2001.

[29] R. N. Landers and J. W. Lounsbury, "An Investigation of Big Five and Narrow Personality Traits In Relation To Internet Usage," Computers in Human Behavior, vol. 22, no. 2, pp. 283-293, 2006.

[30] F. D. Davis, R. P. Bagozzi, and P. R. Warshaw, "User Acceptance of Computer Technology: a Comparison of Two Theoretical Models," Management Science, vol. 15, no. 8, pp. 982-1003. 1989.

[31] M. J. S. Franco, "WebCT - the Quasimoderating Effect of Perceived Affective Quality on an Extending Technology Acceptance Model," Computers and Education, vol. 54, no. 1, pp. 37-46, 2010.

[32] M. C. Lee, "Explaining and Predicting Users' Continuance Intention toward e-Learning: an Extension of the Expectation-Confirmation Model," Computers \& Education, vol. 54, no. 2, pp. 506-516, 2010.

[33] S. Kim and G. Garrison, "Investigating Mobile Wireless Technology Adoption: an Extension of the Technology Acceptance Model," Information System Frontiers, vol. 11, no. 3, pp. 323-333, 2009.
[34] M. C. Wu and F. Y. Kuo, "An Empirical Investigation of Habitual Usage and Past Usage on Technology Acceptance Evaluations and Continuance Intention," The Database for Advances in Information Systems, vol. 39, no. 4, pp. 48-73, 2008.

[35] A. Illias, N. M. Suki, M. R. Yasao, and R. A. Rahman, "A Study of Taxpayers' Intention in Using e-Filing System: A Case in Labuan F.T s," Computer and Information Science, vol. 1, no. 2, pp. 110-119, 2008.

[36] M. C. Hung, I. C. Chang, and H. G. Hwang, "Exploring Academic Teachers' Continuance toward the Web-Based Learning System: the Role of Causal Attributions," Computers and Education, vol. 57, no. 2, pp. 1530-1543, 2011.

[37] T. Al-maghrabi, C. Dennis, and S. V. Halliday, "Understanding The Factors That Derive Continuance Intention Of E-Shopping In Saudi Arabia: Age Group Differences In Behaviour," Journal of Enterprise Information Management, vol. 24, no.1, pp. 85-111, 2011

[38] T. Wang, L. B. Oh, K. Wang, and B. Zhang, "An Empirical Study of the Impact of Trial Experiences on the Continued Usage of Mobile Newspapers," in Proc. the Pacific Asia Conference on Information Systems (PACIS), 2010, paper 112, pp. 1148-1159.

[39] Y. S. Kang and H. Lee, "Understanding the Role of an IT Artifact in Online Service Continuance: an Extended Perspective of User Satisfaction," Computers in Human Behavior, vol. 26, no. 3, pp. 353-364, 2010.

[40] P. J. H. Hu, S. A. Brown, J. Y. L. Thong, F. K. Y. Chan, and K. Y. Tam, "Determinants of Service Quality and Continuance Intention of Online Services: The Case of eTax," Journal of the American Society for Information Science and Technology, vol. 60, no. 2, pp 292-306, 2009.

[41] T. J. Larsen, A. M. Sorebo, and O. Sorebo, "The Role of Task -Technology Fit as Users' Motivation to Continue Information System Use," Computers in Human Behavior, vol. 25, no. 3, pp 778-784, 2009.

[42] R. R. McCrae and P. T. Jr Costa, "Validation of the Five-Factor Model of Personality Across Instruments and Observers," Journal of Personality and Social Psychology, vol. 52, no.1, pp. 81-90, 1987.

[43] S. Sahney, K. Ghosh, and A. Shrivastava, "Consumer "Personality" in Railway E-Ticketing: Conceptualization and Empirical Testing in Indian Context," International Journal of Business, Management and Social Sciences, vol. 1, no.1, pp. 9-20, 2010.

[44] I. A. Junglas, N. A. Johnson, and C. Spitzmuller, "Personality Traits and Concern for Privacy: an Empirical Study in the Context of Location-Based Services," European Journal of Information System, vol. 17, pp. 387-402, 2008

[45] R. N. Landers, and J. W. Lounsbury, "An Investigation of Big Five and Narrow Personality Traits In Relation To Internet Usage," Computers in Human Behavior, vol. 22, no. 2, pp. 283-293, 2006.

[46] L. A. Pervin and D. Cervone, Personality: Theory and Research. 11 ed. John Wiley \& Sons (Asia) Pte Ltd. 2010.

[47] H. Saleem, A. Beaudry, and A. M. Croteau, "Antecedents of Computer Self-Efficacy: An Investigation of the Role of Personality Traits," in Proc. the Administrative Sciences Association of Canada (ASAC), Toronto Ontaria, May 28-31, 2005.

[48] J. Y. L. Thong, S. J. Hong, and K. Y. Tam, "The Effects of Post-Adoption Beliefs on the Expectation-Confirmation Model for Information Technology Continuance," International Journal of Human Computer Studies, vol. 64, no. 9, pp. 799-810, 2006.

[49] T. S. H. Teo, S. C. Srivastava, and L. Jiang, "Trust and Electronic Government Success: An Empirical Study," Journal of Management Information Systems, vol. 25, no. 3, pp. 99-131, 2008.

[50] M. D. Myers and L. Miller, "Ethical Dilemmas in the Use of Information Technology: A Aristotelian Perspectives," Ethics and Behavior, vol. 6, no. 2, pp 153-160, 1996.

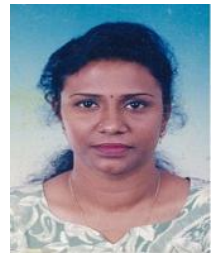

T. Santhanamery is currently a senior lecturer at the Faculty of Business Management in Universiti Teknologi Mara Malaysia. She has thought courses in Business, Management and Economics at diploma and undergraduate level. Prior to this she was an operation officer for Maybank Berhad in year 1996 - 2002. Her experience in banking industry for 6 years was in the area of banking operations and handling customer service. Currently, she is pursuing her $\mathrm{PhD}$ by research in the area of Technology Management in Universiti Sains Malaysia under the scholarship of Ministry of Higher Education (MOHE) Malaysia. Her publications in the area of technology adoption particularly on e-government have appeared in IGI Global and Technics Technologies Education Management (TTEM) Having experience in banking and education industry for almost 16 years, she would like to collaborate and share her experience in technology management and operation management area. 
T. Ramayah is currently a Professor at the School of Management in USM. He has taught courses in statistics, operations management, research methods, forecasting and computer literacy at undergraduate level. He has also presented numerous papers at local and international conferences having won 5 "Best Papers" award. His publications which exceed 300 have appeared in Journal of Environmental Management, Technovation, Computers in Human Behavior, Resources, Conservation and Recycling, International Journal of Information Technology \& Decision Making (IJITDM), International Journal of
Information Management, Lecture Notes in Computer Science, Turkish Online Journal of Education Technology, Journal of Research in Interactive Marketing, Information Development, Journal of Project Management (JoPM), IJITDM, International Journal of Services and Operations Management (IJSOM), Engineering, Construction and Architectural Management (ECAM) and North American Journal of Psychology among others. He also serves on the editorial boards and program committee of several international journals and conferences of repute. His full profile can be accessed from http://www.ramayah.com 